\title{
Robotic-assisted modified retroauricular cervical approach: initial experience in Latin America
}

\section{Abordagem cervical por via retroauricular modificada com uso da técnica robótica: experiência inicial na América Latina}

\author{
Thiago Celestino Chulam ${ }^{1}$; Renan Bezerra Lira ${ }^{1}$; Luiz Paulo Kowalski, TCBC-SP¹.
}

\begin{abstract}
A B S T R A C T
Objective: to evaluate the thickness of the gastric wall at the time of intra gastric balloon (IGB) placement, at the time of its withdrawal and one month after withdrawal. Methods: fifteen morbidly obese patients underwent the introduction of IGB under general anesthesia. In all patients, there was infusion of $500 \mathrm{ml}$ of distilled water in the balloon for the test. Measurements of the thickness of the gastric wall were made in the antrum, body and proximal body, using a radial echoendoscope with a frequency of $12 \mathrm{MHz}$ and maximum zoom, and its own balloon inflated with $5 \mathrm{ml}$ of distilled water. Results: the presence of IGB led to increased wall thickness of the gastric body by expanding the muscle layer. These changes were apparently transient, since 30 days after the balloon withdrawal there was a tendency to return of the wall thickness values observed before the balloon insertion. Conclusion: the use of intragastric balloon for the treatment of obesity determines transient increase in the wall thickness of the gastric body caused by expanded muscle layer.
\end{abstract}

Keywords: Robotic Surgical Procedures. Minimally Invasive Surgical Procedures. Neck Dissection.

\section{INTRODUCTION}

$\mathrm{R}$ obotic surgery was introduced in head and neck oncology about seven years ago, after technical consolidation in other areas, such as Gynecology, Cardiothoracic Surgery and Urology'. In recent decades, cancer surgery of the head and neck has shown remarkable progress, with the development of various types of minimally invasive procedures and improvement in reconstruction techniques. The handling and preservation of structures that are delicate and important from a functional point of view have always been a concern of experts, as well as the concern to reduce morbidity without compromising oncological radicality. Recently, there has been a significant progress in video-assisted minimally invasive surgery, associated or not with the use of equipment that enable this type of technique, such as laser. Among the most recent advances in head and neck oncology, there is the use of the DaVinci robotic system².

The Transoral Robotic Surgery (TORS) is well established and in propagation phase. However, few centers in the world employ the robotic technique in the approach of cervical primary tumors or metastases ${ }^{3}$.

With respect to the robotics technique, it is essential to understand the advantages it can provide and the difficulties it imposes. Among the advantages are: three-dimensional visualization and magnification of the tissues and of the operative field, with multiple viewing angles, higher precision, better ergonomics and possibility of remote access. The main disadvantage is still only economic ${ }^{4}$. The purpose of this Technical Note is to describe the use of the technique robotics performed by modified retroauricular access for cervical surgery.

\section{TECHNIQUE}

The preparation of patients for surgery is the one usual for other neck procedures. The patient should be under general anesthesia and should be positioned on the operating table with a slight cervical extension and rotation of the head to the contralateral side. Recently, it has been observed that the reduction or even the complete removal of the neck extension can facilitate these

1 - Department of Head and Neck Surgery and Otorhinolaryngology, AC Camargo Cancer Center, São Paulo, SP, Brazil. 


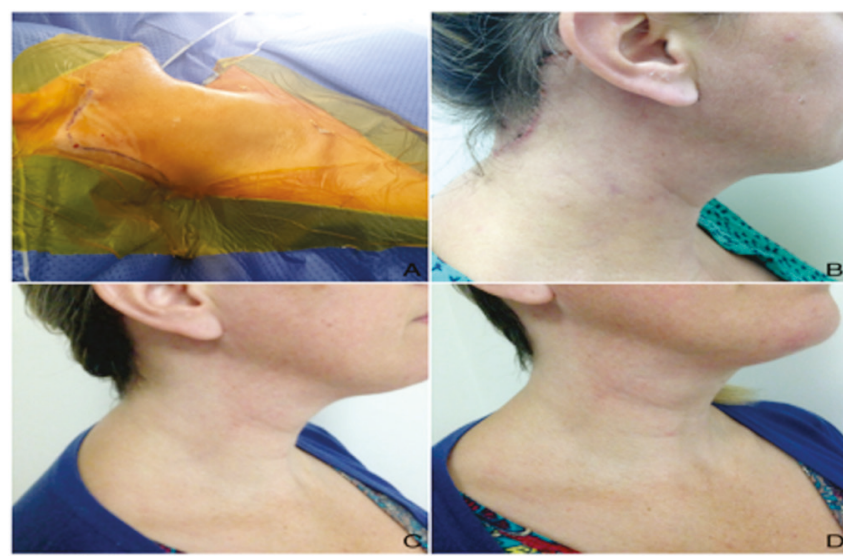

Figure 1. (A) Retroauricular incision; (B) operative wound after one week; (C-D) Appearance of the final scar.

approaches. We make the retroauricular incision (Figure 1) and lift the subplatismal flap, exposing the surgical field limited by the midline of the neck, jaw, omo-hyoid muscle and sternocleidomastoid muscle, as described by the Department of Head and Neck Surgery, Younsei University, South Korea ${ }^{5}$. During the flap lifting, it is important to identify and preserve the great auricular nerve and the external jugular vein, which are reference points to find the platysma muscle. After that, we place the Bookler autostatic retractor, which provides an appropriate working space. We then perform the neck dissection (Figure 2), the resection of the submandibular or cervical tumor with the aid of the DaVinci system (2 arms - right arm with Ultracision and left arm with Maryland) and vascular clips (Hemolock ${ }^{\mathrm{TM}}$ ). We carry out any dissections lateral to the carotid artery under direct vision, using frontal focus. The preservation of the marginal branch of the facial nerve, vagus, hypoglossal, lingual, and accessory phrenic nerves occurs routinely, as in the conventional procedure. We perform closed aspiration drainage (Blake $\left.{ }^{\mathrm{TM}}\right)$ in all cases.

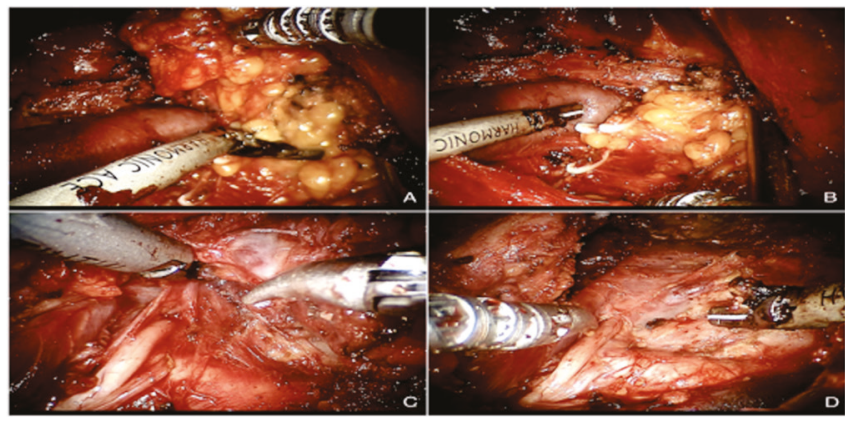

Figure 2. Ongoing neck dissection and the magnification of the dissected structures. (A-B) Level IV dissection with preservation of the internal jugular vein and clipping of the lymphatic vessels; (C-D) Levels II-III dissection with display of the hypoglossal nerve and carotid artery.

\section{DISCUSSION}

So far, we performed seven procedures using this type of approach. There were six selective neck dissections (SND), five SND of levels I to III and one SND of levels I to IV. The other procedure was a thyroid lobectomy with isthmectomy. The most frequent complication was paresis of the facial marginal branch. There were no bleeding or infection. The only thyroidectomy had no complications related to the recurrent nerve, which was well identified and maintained. In surgical specimens of neck dissections, 13-30 lymph nodes were found.

Thus, after team training in a Seoul certificate center and experience with TORS, we started the use of cervical robotic surgery. Our initial experience indicates that this approach is feasible, safe and effective and can be used in selected cases with an obvious cosmetic benefit. Functional and oncological evaluation requires a longer follow-up.

\section{R E S U M O}

A preocupação com a melhoria dos resultados estéticos e funcionais sem comprometimento dos resultados oncológicos na cirurgia de cabeça e pescoço tem aumentado significativamente. Os procedimentos minimamente invasivos e principalmente aqueles que utilizam a tecnologia robótica permitiram o desenvolvimento de novas abordagens, incluindo o acesso retroauricular, que agora é usado rotineiramente, especialmente na Coréia do Sul. A presente nota irá ilustrar a técnica e a experiência inicial na América Latina, demonstrando que esta abordagem é viável, segura e eficaz oncologicamente, podendo ser utilizada em casos selecionados com um benefício estético evidente.

Descritores: Robótica. Procedimentos Cirúrgicos Minimamente Invasivos. Esvaziamento Cervical. 


\section{REFERENCES}

1. Dasgupta P, Kirby RS. The current status of robot-assisted radical prostatectomy. Asian J Androl. 2009;11(1):90-3.

2. Lee HS, Kim D, Lee SY, Byeon HK, Kim WS, Hong HJ, et al. Robot-assisted versus endoscopic submandibular gland resection via retroauricular approach: a prospective nonrandomized study. $\mathrm{Br} J$ Oral Maxillofac Surg. 2014;52(2):179-84.

3. Chen MM, Roman SA, Kraus DH, Sosa JA, Judson BL. Transoral robotic surgery: a population-level analysis. Otolaryngol Head Neck Surg. 2014;150(6):968-75.

4. Kim KH, Choi HG, Jung YH. Head and neck robotic surgery: pros and cons. Head Neck Oncol. 2013;5(3):26.

5. Lee HS, Kim WS, Hong HJ, Ban MJ, Lee D, Koh YW, et al. Robot-assisted Supraomohyoid neck dissection via a modified face-lift or retroauricular approach in early-stage cNO squamous cell carcinoma of the oral cavity: a comparative study with conventional technique. Ann Surg Oncol. 2012;19(12):3871-8.

Received in: 26/01/2016

Accepted for publication: 04/05/2016

Conflict of interest: none.

Source of funding: none.

\section{Mailing address:}

Thiago Celestino Chulam

E-mail: thiagochulam@yahoo.com.br /

renanblira@hotmail.com 